\title{
Study on Financial Support of Coal Enterprises in Shaanxi Province to Develop Low-Carbon Economy
}

\author{
Penglin Li, Zhengmei Li \\ School of Management, Xi'an University of Science and Technology, Xi'an, China \\ Email: Ipl@vip.163.com
}

Received 13 July 2015; accepted 22 August 2015; published 25 August 2015

Copyright (C) 2015 by authors and Scientific Research Publishing Inc.

This work is licensed under the Creative Commons Attribution International License (CC BY). http://creativecommons.org/licenses/by/4.0/

cc) (i) Open Access

\begin{abstract}
Nowadays, the development of low-carbon economy is advocated and the carbon finance has become an important factor to promote the development of low-carbon economy. Taking advantage of the power of the carbon finance to give full play financing function of the green credit and financial institutions and achieve low-carbon technology innovation for coal enterprises has become the key to realize the sustainable development. Taking Shaanxi coal enterprises as a sample, this paper deeply discusses existing problems and its causes in the process of developing lowcarbon economy in coal enterprise supported by Shaanxi finance, and then put forward the suitable financial support and policy path accordingly.
\end{abstract}

\section{Keywords}

Low-Carbon Economy, Coal Enterprises, Financial Support, Path Selection

\section{Introduction}

Shaanxi is one of provinces which have rich resources of coal in China; coal industry is a pillar industry in Shaanxi Province, which consumes large energy and emits a lot. According to statistics, in 2012, the coal consumption of coal enterprises accounted for 30.5\% of total consumption of five large energy consuming industry, including mining, manufacturing, construction, transportation and electricity, gas and water production and supply and ranked the second among the five industries. Carbon emission of Shaanxi Province increased from 64 million tons to 0.3 billion tons from 2000 to 2013, growing by about 26.6\% per year which amounts for one tenth of the total carbon emissions of Shaanxi Province. At the same time, the coal production process is also accompanied by the emission of gas, coal gangue, coal mine water etc. These resources will seriously pollute the 
environment if not reasonably used. Therefore, improving the low-carbon technology of coal enterprises, and carrying out energy-saving and emission reduction measures from its root are very important for the low-carbon development of Shaanxi province. And at the present stage, there are less large-scale coal enterprises and more small private coal enterprises in Shaanxi Province. Since 2012, the operating environment of the coal enterprise changes greatly; the vast majority enterprises are in deficit condition, serious lack of funds and difficult to bear high cost to develop low-carbon technologies and buy advanced coal washing, coal preparation equipment, resulting in lacking of technical personnel, lagging behind of mechanical equipment, low rate of coal mining and washing and short industrial chain. It is undoubtedly impossible to fundamentally solve these problems without adequate financial support. In a sense, whether it can effectively solve the shortage of funds issue matters the success or failure of the low-carbonization process of Shaanxi Province and is the core problem which needs to be solved for coal enterprises to realize low-carbonization development.

Being the core of modern economy, finance can not only provide direct or indirect capital support to coal enterprises so as to accelerate their technological transformation and eliminate the backward technology, but also can offer all-round financial services, reducing the risks the enterprises take in the process of developing the low-carbon technology. Therefore, it is of great practical significance to study the financial support for the coal enterprises in Shaanxi province to develop the low-carbon economy.

Researches on the finical support for the development of low-carbon economy in China and abroad mainly focus on two aspects. The first aspect is about the necessity and importance of financial support for the low-carbon economy. Among these studies, Sonia Labatt and Rodney R.White (2010) explained the connotation of carbon finance in a much broader way, revealing the financing function and risk management the financial instruments play in the financial market [1]. Lewis. J. I. (2010) pointed out that the clean development mechanism benefited the developing countries in greenhouse gas emissions [2]. Jian Kui (2006) analyzed the necessity of green finance from three aspects: natural ecology, economic development and financial institutions [3]. And the second aspect is about the strategic research of financial support for low-carbon economy. Jeucken (2001) [4] thought that the banking industry was the main front of the development of green finance, and it was closely related with the environmental protection. Martin Nell and Andreas Richter (2000) [5] jointly studied the management innovation of green finance business in insurance industry, and pointed out that the insurance industry should create the targeting product to control the risk according to climate change. Xu Jianyu (2008), Liu Huanhuan (2009), Lu Zhaoyang (2011) proposed to use financial derivative instruments like funds, futures and options to improve the energy utilization and develop the low-carbon technology [6]-[8]. Ren Li (2009), He Chengying (2001) and Huang Chongjie (2011) believed that banks, securities, insurance can provide a multidimensional financial support for low-carbon industries [9]-[11].

At present, most domestic and foreign researches focus on the meso or macro level, starting from one industry or one country to discuss the ways for the finance to support low-carbon economy and the corresponding policy. As for the writer, the study on the financial support of the low-carbon economy should not only start from the macro level so as to provide basis for the policy making of the national industry and trade, but also locate on the micro level to discuss the specific measures the enterprises take to develop their low-carbon economy. For the coal industry, we need to study the concrete measures in terms of the technology, personnel, capital, and ideas to realize the low-carbon economy. Since the policy, which is at the macro level, have to be carried out through the enterprises, which are at the micro level, the studies on the latter aspect seem more important. But present researches on this aspect are relatively fewer, let alone studies on the coal industry from the micro aspect. Based on the above research background, combining the current situation of low-carbon economy of coal enterprises in Shaanxi Province, this paper starts from the micro level of local coal enterprises and puts forward suitable ways for Shaanxi Finance to support the coal enterprises to develop the low-carbon economy.

\section{Analysis of Present Financial Support for Coal Enterprises' Developing Low-Carbon Economy in Shaanxi Province}

In 2009, the officially proposal of "coal, oil and gas development environment protection regulations of Shaanxi province" and "energy saving regulations of Shaanxi province" marked the beginning of energy saving and emission reduction in Shaanxi province. Since then, Shaanxi Province promulgated many related policies and regulations to support coal enterprises to carry out energy-saving and emission reduction and encourage financial institutions to support low-carbon industry; the major financial institutions in Shaanxi Province, such as 
Shanghai Pudong development Bank, Agricultural Bank of China, China Everbright Bank all increased the credit support to the coal enterprises. But it is far from enough for the huge capital and multi dimensional financial services that are needed for the development of the coal enterprise. Insufficiencies also exist in many ways; the specific performances are as following.

\subsection{Insufficient Financial Support for Coal Enterprise of Shaanxi Province}

The level of low-carbonization of coal enterprises in Shaanxi Province is very low, which needs huge capital investment to eliminate laggard production capacity and reduce waste emissions, but Shaanxi province's investment on coal enterprise investment is relatively small. The total investment of Shaanxi Province in 2009 is 525.1 billion yuan, including investment in the mining industry for 611 billion yuan which accounted for $11.6 \%$ of the total investment and investment on the coal mining and dressing industry for 243 million yuan which only accounted for $4.6 \%$ of the total investment. In 2010, the mining industry investment is 875 billion yuan, accounting for $12.5 \%$ of the total investment; coal mining and washing industry investment is 344 billion yuan, accounting for $4.9 \%$ of the total investment. By 2012, the mining industry investment is 155.5 billion yuan, accounting for $12.4 \%$ of the total investment; coal mining and washing industry investment accounts for $6.4 \%$ (see Figure 1).

Also from the R \& D (Research and development) which reflects the support of new scientific and technical of a country, region or enterprise, we can see though R \& D funds in Shaanxi Province has been in growth in recent years, $R$ \& D/GDP strength is low and also shows a descending trend in recent years, as shown in Figure 2, indicating that the support to new technologies of Shaanxi Province gradually weakens.

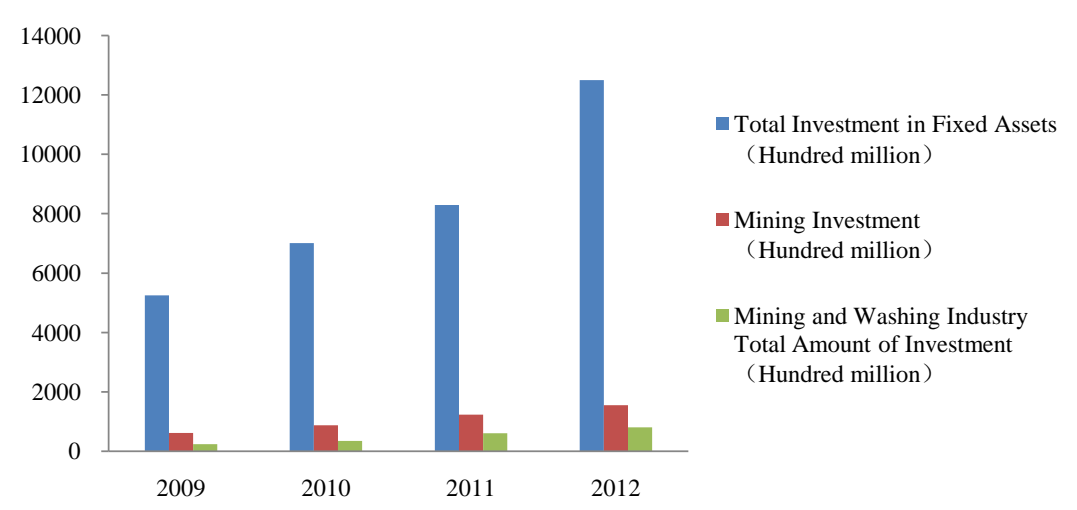

Figure 1. Investment situation of Shaanxi province on coal industry. Data source: Statistical yearbook of Shaanxi Province.

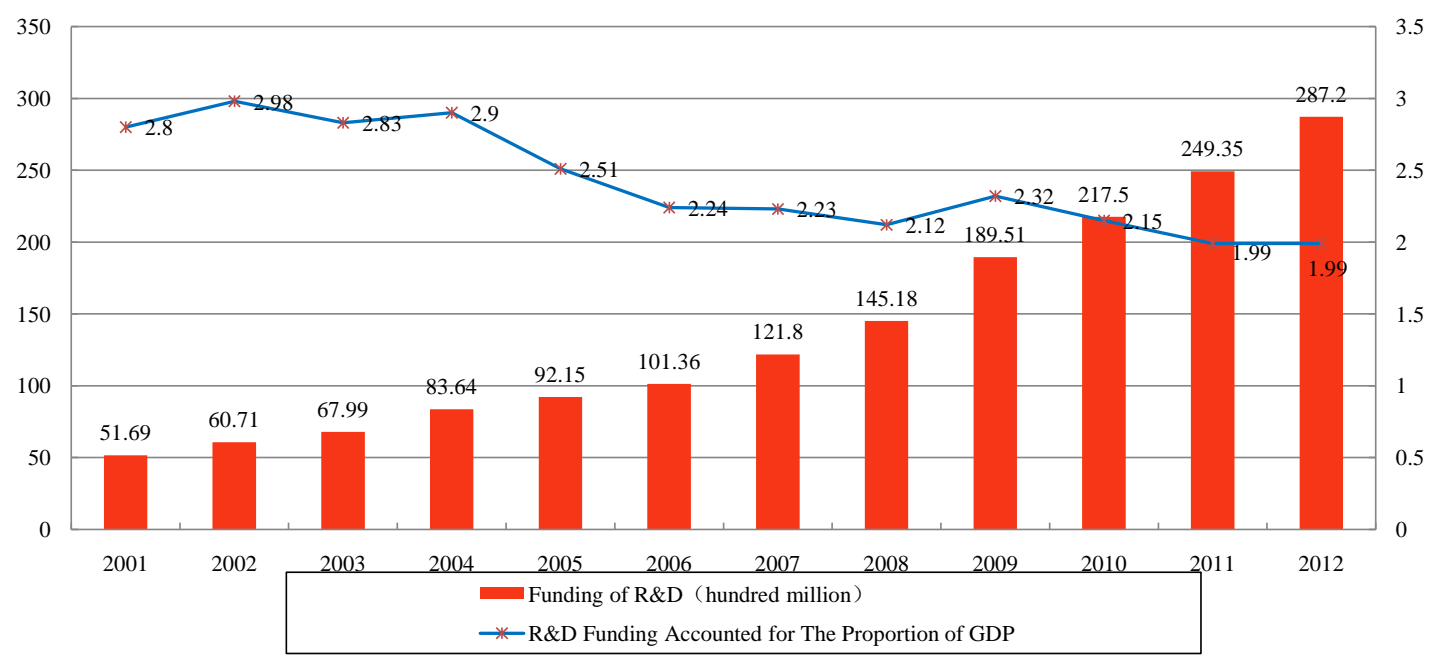

Figure 2. Proportion of Shaanxi province R \& D fund to total output value. 


\subsection{Inadequate Green Credit of Bank}

Table 1 is the balance of China major commercial banks' green-credit, from which we can see commercial bank's green loans are on a smaller scale, as fewer than $5 \%$ of total assets and green credit only accounts for about $1 \%$ of China's total commercial bank assets, the financing gap is up to 20 times of the existing financing. "2014 annual report of China low-carbon finance development" shows, of the researched China commercials, its green credit accounts is less than $2 \%$; green credit balance of 18 major commercial banks of which the total assets ranking in front accounts for about $1.81 \%$ of the total; Industrial Bank ranking first with green credit accounted for only $3.46 \%$.

\subsection{Single low-Carbon Finance Product}

Low-carbon industry is promising but has the characteristics of capital intensive and high risk; the original financial products cannot meet the need of the its development; China CDM (Clean Development Mechanism) project transactions and voluntary emission reduction transactions are spot exchange of carbon dioxide, and only stay in a carbon commercialization stage, and related derivative products with carbon finance, such as carbon futures and carbon option, carbon swaps have not yet appeared. Although Shaanxi Province is a province with huge amount of coal, it is also the first province to explore the low-carbon economy; as for the low-carbon financial products, Shaanxi only stays in the initial stage of low-carbon credit. In China, carbon funds are mainly public offering fund, which dedicates to the CERs (Certification Emission Reductions) and carbon emission right. There is little low-carbon fund initiated by fund company (see Table 2). And in the low-carbon bonds, only CGN Wind Power Co., Ltd. issued the first single carbon bonds of 10 billion yuan and 5 years time limit in May 2014-CGN wind power and carbon gain medium-term notes.

Table 1. The balance of green credit of China commercial bank.

\begin{tabular}{|c|c|c|c|c|c|c|c|c|c|c|}
\hline \multirow{2}{*}{ Bank } & \multicolumn{2}{|c|}{$\begin{array}{c}\text { China } \\
\text { Construction } \\
\text { Bank }\end{array}$} & \multicolumn{2}{|c|}{$\begin{array}{l}\text { Industrial and } \\
\text { Commercial } \\
\text { Bank of China }\end{array}$} & \multicolumn{2}{|c|}{ Industrial Bank } & \multicolumn{2}{|c|}{$\begin{array}{l}\text { Shanghai Pudong } \\
\text { Development Bank }\end{array}$} & \multicolumn{2}{|c|}{ China Merchants Bank } \\
\hline & $\begin{array}{l}\text { Balance of } \\
\text { green credit } \\
\text { (billion) }\end{array}$ & $\begin{array}{l}\text { Ratio to } \\
\text { total } \\
\text { assets (\%) }\end{array}$ & $\begin{array}{l}\text { Balance of } \\
\text { green credit } \\
\text { (billion) }\end{array}$ & $\begin{array}{l}\text { Ratio to } \\
\text { total } \\
\text { assets (\%) }\end{array}$ & $\begin{array}{l}\text { Balance of } \\
\text { green credit } \\
\text { (billion) }\end{array}$ & $\begin{array}{l}\text { Ratio to } \\
\text { total } \\
\text { assets (\%) }\end{array}$ & $\begin{array}{l}\text { Balance of } \\
\text { green credit } \\
\text { (billion) }\end{array}$ & $\begin{array}{l}\text { Ratio to } \\
\text { total } \\
\text { assets (\%) }\end{array}$ & $\begin{array}{l}\text { Balance of } \\
\text { green credit } \\
\text { (billion) }\end{array}$ & $\begin{array}{c}\text { Ratio to } \\
\text { total } \\
\text { assets (\%) }\end{array}$ \\
\hline 2008 & 154.1 & 2.0 & 49.2 & 0.5 & 3.3 & 0.3 & 12.3 & 0.9 & 24.9 & 1.7 \\
\hline 2009 & 181.1 & 1.9 & 408 & 3.5 & 16.6 & 1.2 & 17.5 & 1 & 39.8 & 2 \\
\hline 2010 & 195.8 & 1.8 & 507.5 & 3.8 & 47.9 & 2.6 & 21.5 & 0.98 & 46.2 & 1.9 \\
\hline 2011 & 219.1 & 1.8 & 590.4 & 3.8 & 88.4 & 3.7 & 25.5 & 0.95 & 51 & 1.8 \\
\hline 2012 & 239.6 & 1.7 & 598 & 3.4 & 112.6 & 3.5 & 25.6 & 0.82 & 109.5 & 3.2 \\
\hline 2013 & 488.4 & 3.2 & 593.4 & 3.1 & 178.1 & 4.8 & 24.3 & 0.66 & 116.4 & 2.9 \\
\hline
\end{tabular}

Data sources: The annual social responsibility report of each bank, Annual report of China Construction Bank, Annual Sustainability development report of Industrial Bank.

Table 2. The main low-carbon fund in China.

\begin{tabular}{|c|c|c|c|}
\hline Name & Type & Scale & Investee \\
\hline China Carbon Fund & Public fund (solicitation) & & Emission volume in different type of CDM projects \\
\hline China Green Fund & Public fund (solicitation) & & Carbon sink \\
\hline $\begin{array}{l}\text { China Clean Development } \\
\text { Mechanism Fund }\end{array}$ & $\begin{array}{l}\text { Public fund } \\
\text { (solicitation) }\end{array}$ & & Activities in the field of climate change \\
\hline Huatan Fund & Private fund & & Support and develop Carbon emission reduction Index \\
\hline Jiatankaiyuan Fund & Private fund & & CCER (Chinese Certified Emission Reduction) \\
\hline $\begin{array}{c}\text { Special asset management } \\
\text { plan on carbon emission right }\end{array}$ & Closed fund & 30 million & Carbon emission right exchange \\
\hline Haitongbaotan Fund & Closed fund & 0.2 billion & China Certified voluntary emissions \\
\hline Huifengjinxin Fund & Public fund, stock fund & & Public company in the field of low-carbon \\
\hline
\end{tabular}

Data source: http://www.tanjiaoyi.com/. 


\subsection{Low Participation of Non-Banking Financial Institutions and Single Financing Channels of Coal Enterprises}

At present, the fund for coal enterprises to research and develop low-carbon technology and purchase low-carbon equipment is mostly from government investment and bank loan, normally about hundreds of millions or more; investment projects generally need many years' of experimental operation so as to produce economic benefits, only large-scale coal enterprises can withstand this kind of high risk projects. Only if these fund institutions, securities institutions and insurance institutions, etc with powerful social influence involved can make coal enterprises develop low-carbon economy really and clean the coal. Insurance companies can also follow the examples of foreign to insure coal companies who sell the carbon credit, securities companies and other underwriters institution can give full play to the function of the capital market, helping companies to issue medium-term notes, short-term financing bonds to broaden the source of financing for enterprises.

\subsection{Imperfect Intermediary Market of Carbon Market}

\section{1) Imperfect Intermediary Market of CDM Project}

At present, China has the world's most registered CDM projects; by August 31, 2014, the United Nations Executive Board disclosed China 3762 CDM registration items [12]. At the same time, China is the biggest supplier of certified emission reductions (CERs) country in the world's primary market. Since 2005, our country provided certified emissions more than half of the world's total supply each year. The certified emission is the carbon emissions generated under the CDM project, which can be used as a kind of current assets in the international market. Shaanxi is a province with huge amount of coal; coal companies emit a large number of carbon dioxide in the air every year; if the sale of CERs is based on the CDM project, huge profits will be generated. But due to the strict carbon credit trading rules, complex development procedures, sales contract involving foreign customers, long contract duration [13], the relevant agencies are hard to act as CDM intermediary to find a buyer for enterprises in the world. At present, in China, only Shanghai Pudong Development Bank, China Minsheng Bank, Agricultural Bank of China participates in the CDM project. Agricultural Bank of China and enterprise reached the CDM project cooperation letter of intent; the Shanghai Pudong Development Bank hold the position as financial advisor of CDM projects to companies, China Minsheng Bank launched financing mode that using revenue of CERs projects generated in the CDM as enterprise repayment sources.

\section{2) Weak Function of the Environmental Right Exchange}

Although Shaanxi Province established the environmental rights exchange, there are many disadvantages, such as less trading varieties, narrow trading range, less trading number and turnover. By the end of January 2014, there are only $\mathrm{SO}_{2}$ emissions right and chemical oxygen demand amount and ammonia nitrogen emissions bid transaction, while other pollutant emissions trading, energy-saving and environmental protection technology transfer, CDM projects especially carbon emissions, carbon trading are not involved. Currently only 14 companies involved in the transaction, of which the coal enterprises participated are Zizhou County Yongxing Coal Mine, Shaanxi Binchang Mining Group Co., Ltd., Huangling Coal Mine, Shenmu Daliuta Shuijingqu coal mine. And the transaction process of Shaanxi provincial environmental right is very simple; mainly lead by the provincial government, and the role of the market mechanism is not fully played.

\section{Analysis of the Reasons for Insufficient Financial Supports to Coal Enterprises to Develop Low-Carbon Economy}

\subsection{Insufficient Knowledge of Financial Institutions to Low-Carbon Economy}

\subsubsection{Inadequate Awareness to Support for Low-Carbon Economy}

According to "report of green credit of 2012", among the banks ranking in front of 50 of China, only Industrial Bank is level A (more than 80 points). Six banks are Level B (60 - 80 points). 42\% banks are level E (less than 20 points). Only 12\% banks execute the green credit fully, 18 banks have no information about green credit. In the day of all countries devote to carbon business, from the relative business of China commercial banks, we can see that they pay inefficient attention to carbon finance.

\subsubsection{Insufficient Recognition to the Value of Low-Carbon Finance Market}

In the international market, carbon trade scale is increasing year by year, which got 1760 in 2011, increasing by 
24\% comparing with 2010 (see Figure 3). According to related market information, the price of carbon emissions right will rise by $61 \%$ by June 30, 2015.Group AG UBS said that in 2015, the cost of carbon emissions may be more than doubled. In the fourth quarter of 2015, the United States California carbon market auction, the supply of the entire carbon quota in 2016 is sold, and the price is higher than the previous by $39 \%$. Carbon finance market will be in short supply situation in 2016. It can be seen that the low-carbon financial market develops rapidly, the market value is increasing, but the financial institutions of our country do not understand the phenomenon and have low market participation awareness.

\subsection{Potential Risk of Low-Carbon}

Coal low-carbon projects have the characteristics of long construction period and slow effect; such as a coal chemical project, from the implementation of the study to coal chemical products production, the scale of investment will reach tens of billions yuan, investment cycle will be in more than five years, and market awareness to low-carbon products is low. All of these will make the coal enterprises face greater market risk and technology risk. In addition, there are growing calls for companies to internalize the environment cost, which increases the cost of business. Coupled with the decline of coal prices, difficulties of operation, small and medium enterprises are facing the risk of bankruptcy. And now, our country is lack of risk sharing and benefit compensation mechanism for financial institutions. Financial institutions haven't perfect risk management system in the field of carbon finance and are lack of comprehensive risk management personnel. Therefore, for the sake of the low-carbon prospect and their own risk management level, very few financial institutions would like to provide security and long-term loans to coal enterprises.

\section{Path for Shaanxi Province Financial Institutions to Support Coal Enterprises for Developing Low-Carbon Economy}

\subsection{Build Perfect Financial Policies System}

Low-carbon economy is a long and complex system project, involving multipartite' interest; perfect government policy system is the necessary support for the coal enterprises in Shaanxi province to achieve low-carbon economy. It is needed to establish corresponding incentive policies and use financial means to help coal enterprises to develop low-carbon economy. Government should eliminate various unreasonable taxation on coal enterprises, effectively reduce the burden of the coal enterprises, provide low tax, tax reduction, tax exemption, interest subsidy for those enterprises developed new low-carbon technologies and new energy, provide fiscal subsidies, tax returns, value-added tax deduction for the enterprises which purchased equipment that are in line with low-carbon technology requirements; set up special funds for low-carbon to reward those who achieved major breakthrough in the study of low-carbon technology.

The reason that financial institutions are lack of motivation of loaning to coal enterprises is very much that the government doesn't do very well in the risk compensation and tax relief for financial institutions. Therefore, Shaanxi Province should introduce relevant policies, provide tax incentives and special funds for financial insti-

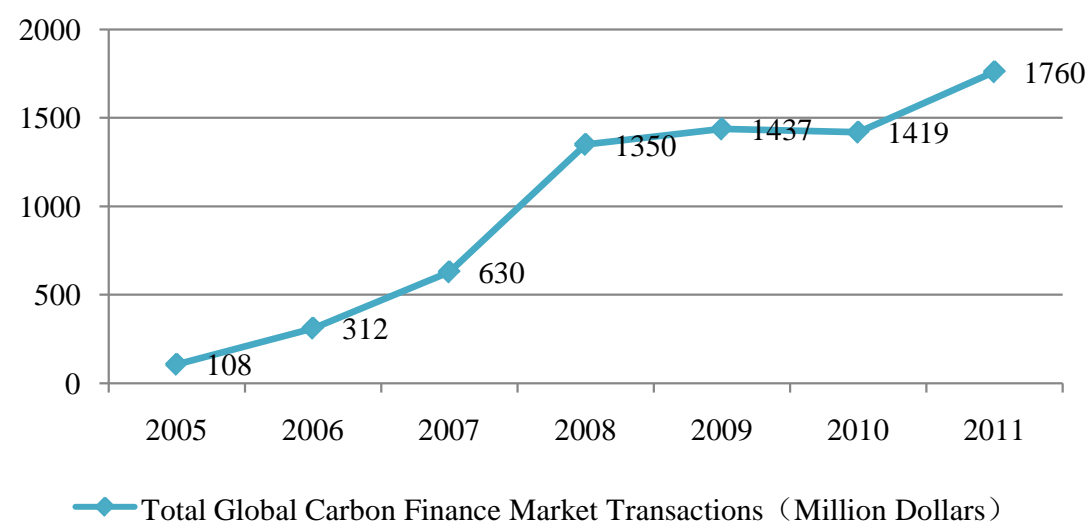

Figure 3. Global transactions of carbon finance. Data resource: state and trends of the carbon market 2012, Word Bank. 
tutions to load to coal enterprises, and guarantee for key national or provincial energy-saving projects to loan from bank and reduce the bank's operational risk and cost. Government should encourage environmental protection departments to provide enterprise' evaluation information about environmental behavior so as to make up the defection that market information and supporting mechanism are relatively backward.

As for the coal enterprises, the capital investment is the key to develop low-carbon economy; financial institutions should establish enterprises tracking system and strengthen audit efforts and examine strictly for corporate philosophy, corporate management and funds using. In the course of funds using, enterprises should be required to submit regular reports of enterprise development and funds using etc., and banks have a regular check of enterprises on site [14]. Enterprise should strengthen communication and cooperation with the environmental protection department, clarify requirements for assessment of environmental review and objectively and rationally analysis and judgment on the future development and growth of the enterprise, and guide the credit funds to invest.

\subsection{Increase Banks' Green Credit}

Although financial institutions in Shaanxi Province provide low-carbon enterprises for some support, coal enterprises need massive capital in the process of low-carbon and financial institutions are unable to meet the demand. Financial institutions can implement different loans; as for high energy consumption and high pollution enterprises , they can implement "veto power", as for enterprises with technology and market prospect, they can reduce the security requirements, simplify loan procedures; as for low-carbon projects of small coal enterprises, they can implement micro-credit, as for large-scale coal enterprise's low-carbon projects, they can give a long loan period and the preferential interest rate; the financial institutions should actively provide long-term mechanism of financial services for energy conservation and environmental protection, strengthen the independent evaluation of low-carbon technology, increase the enterprise green loans under the premise of security benefits [15].

\subsection{Build Perfect Financial Product System}

In the face of the single low-carbon financial product and services in Shaanxi Province, it is the inevitable choice to build a perfect low-carbon financial products system to help the coal enterprises to develop low-carbon economy. International carbon options, carbon securities, carbon futures and other derivatives of innovative products appeared, China only has carbon funds, carbon securities, carbon bonds and other financial products. Shaanxi Province should encourage financial institutions to develop carbon finance derivative products, such as the coal industry development fund, low-carbon technology support funds for coal enterprises, and new energy development fund according to the characteristics of its own development. Shaanxi Province give full play to the characteristic of carbon fund and carbon financial, such as large fund size, long closed time, and advantages of hedging of carbon options and futures, disperse the risk enterprises beard and solve the problem of financing for enterprises.

\subsection{Promote the Participation of Non-Bank Financial Institutions and Broaden Financing Channels of Enterprises}

So far, China's seven major carbon emission right trading pilots have achieved very good results; Shaanxi Provincial Environmental Rights Exchange should fully play the role of trading platform, as soon as possible to become a carbon emissions trading pilot, take up as the intermediary role between CDM projects and carbon finance international trade, formulate detailed corresponding trading rules, carry out carbon dioxide emissions trading, encourage coal enterprises' participation, put the market mechanism in full effect and make passive enterprises play a leading role. People's Bank of China should set up window guidance to lead commercial bank finance low-carbon enterprise. China Securities Regulatory Commission should lower the bar of entering into the capital market enterprise according to operation condition and set up "low-carbon plate" to help coal enterprises to get finance. Commission according to the business situation, the appropriate reduction of coal enterprises into the market threshold, can set up a low-carbon plate, to help coal enterprises financing. Securities companies can help companies issue capital securities, increase the financing of low-carbon enterprises. Credit rating agencies assess low-carbon enterprises objectively and fairly to help their smooth distribution of all kinds 
of financing securities. Insurance companies can develop and design insurance products which are suitable for the development of low-carbon economy, provide security for the related low-carbon projects and reduce the risk of coal enterprises. Fund companies have the characteristics of adequate capital and long duration of the funding to and can provide sustained financial support for a long time for the research of low-carbon projects. The finance leasing company can lease the advanced low-carbon equipment to help enterprises to eliminate backward production capacity. Anyway, only through all types of financial institutions' actively participation can capital market's function is fully played, direct financing and indirect financing be used together and smooth flow of funds be ensured.

\subsection{Improve the Financial Institutions' Acquaintance to Low-Carbon}

Environment today is getting worse and worse; low-carbon-economy is bound to be the future world's economy development trend; carbon finance will also become one of the core businesses of the financial institutions in the future. Financial institutions should soberly realize this point, and be as soon as possible to set up own low-carbon research departments, make full use of the unique talent advantage of Shaanxi Province, strengthen cooperation between schools and enterprises and train professional low-carbon financial talent. Coal enterprises should develop low-carbon financial products, strengthen cooperation with the international financial institutions, study international carbon trading market rules, be familiar with the carbon emissions trading operation process so as to strive for more right to speak; carry out the relevant technical training on the carbon trading, clean development mechanism, carbon clearing and other related technologies, create a professional low-carbon financial team; establish their own low-carbon information assessment system and low-carbon risk defense mechanism and enhance their own risk management level.

\section{Conclusion}

There are many difficulties and problems in the low-carbon process of Shaanxi coal enterprises, and it is urgent to accelerate the development of low-carbon economy in Shaanxi province and even the whole country. And finance is the core of the economy, the development of all economic things cannot be without financial involvement. Although Shaanxi Province has introduced many policies in recent years, provincial environmental exchange got preliminary development; financial institutions give a certain degree of credit support to coal enterprises; a series of problems still exist such as provincial government investment scale, financial institutions green credit and participation awareness, CDM intermediary quantity, understanding of financial institutions towards low-carbon economy. Though a variety of ways to fundamentally solve the problem, such as, constructing a perfect financial policy system, increasing bank's green credit, constructing perfect financial products system, promoting the participation of non-bank financial institutions is the only way that Shaanxi coal enterprises to achieve low-carbonization development.

\section{Fund}

This paper is funded by Shaanxi Province soft science research project "Research on the Energy Low-carbonization path in Shaanxi Province" (2013KRM05) and Shaanxi Province Department of Education special research project "The Development Path and Policy Orientation of Shaanxi Province Coal Industry Low-carbon Economy from the Industrial Chain Perspective” (12JZ016).

\section{References}

[1] Xu, Y. (2012) Research on the Financial Support on Low-Carbon Economy Development in Anhui Province. Anhui University, Hefei.

[2] Lewis, J.I. (2010) The Evolving Role of Carbon Finance in Promoting Renewable Energy Development in China. Energy Policy, 38, 2875-2886. http://dx.doi.org/10.1016/j.enpol.2010.01.020

[3] He, J.K., Jiang, T. and Wang, J.L. (2006) Green Finance and Economic Sustainable Development. Ecological Economy, 6, 78-81.

[4] Jeucken (2010) Benchmarking for Competitive Advantage. McGraw Hill, New York.

[5] Nell, M. \& Richter, A. (2000) Business Process Benchmarking: Finding and lmplementing Best Praetiees. ASQC Quality Press, Millwaukee Wise. 
[6] Xu, J.Y. (2008) How to Build the Country’s Financial Reform and Innovation Base-Learned from International Experience. Economy, 6, 26-30.

[7] Han, X.M. and Liu, H.H. (2009) Dynamic Comparative Study on Ecological Consumption and Economic Development in China-Consideration on the Low Carbon-Economy in the West Region. Journal of Lanzhou University, 37, 118-125.

[8] Shen, B., Ran, G.H. and Lu, Z.Y. (2011) Research Progress of Carbon Finance Problems in China. Inquiry into Economic Issues, 9, 148-152.

[9] Ren, L. (2009) Policy and Enlightenment of Foreign Low-Carbon Economy Development. Development Research, 2, 47-50.

[10] He, C.Y. (2001) City System Reform and Capital Market Innovation. Economic Research Journal Research, 6, 22-25.

[11] Ren, L. and Huang, C.J. (2009) Can China Financial Development Affect Energy Consumption-Based on Dynamic Panel Data? Economic Management, 2, 47-50.

[12] http://www.tanpaifang.com/CDMxiangmu/2014/1003/38806.html

[13] Yang, J.Q. (2014) Research on the Development and Countermeasure of Carbon Finance Development Based on Clean Development Mechanism. Science Mosaic, 8, 165-168.

[14] Xue, S.L. and Sun, H. (2011) Models and Measures of Low-Carbon Economy Development Supported by Green Finance. Economic Herald, 10, 36-37.

[15] Li, P. (2010) Research on the Financial Support for Low-Carbon Economy. Theoretical Investigation, 5, 67-70. 